\title{
Antifungal activity of essential oil of Amyrisbalsamifera against Cryptococcusneoformans
}

\author{
Fernando Abrão ${ }^{1}$, Lorena Peixoto ${ }^{2 *}$, Marcelo Ramada ${ }^{3}$, Mariana Oliveira ${ }^{1}$, Ana Flávia Mendonça ${ }^{1}$, Carolina Treméa ${ }^{1}$, \\ Lucia Souza', Maria Silva'
}

From 5th Congress of the Brazilian Biotechnology Society (SBBIOTEC)

Florianópolis, Brazil. 10-14 November 2013

\section{Background}

Cryptococcus neoformans can cause infection in immunocompromissed individuals, especially in patients with acquired immunodeficiency syndrome, in which meningoencephalitis is the main clinical manifestation [1]. There are few available antifungals for cryptococcosis treatment and all of them present high toxicity, besides the reports of resistance. In this context, the natural products from plants are an important source in the search for new antifungal compounds. In this study, it was evaluated the antifungal activity of the Amyrisbalsamifera essential oil (EO) against $C$. neoformans. The determination was made by minimum inhibitory concentration (MIC) and minimum fungicidal concentration (MFC) using the microdilution broth method.

\section{Methods}

Broth microdilution protocols based on the CLSI reference document M27-A3 [2], were used to determine MIC values for 15 isolates of C. neoformans. Briefly, twofold serial dilutions, in Roswell Park Memorial Institute (RPMI 1640) broth, with final test concentrations ranging from 2 to $1024 \mu \mathrm{g} / \mathrm{mL}$ for $A$. balsamifera was tested, and the inocula was prepared in the same broth with $10^{3}$ yeasts/ $\mathrm{mL}$. Results were read after $72 \mathrm{~h}$, and MICs were defined as the lowest test concentrations causing complete growth inhibition. Quality control determinations of the MIC values of fluconazole were performed by testing Candida parapsilosis ATCC 22019 and the results obtained were within the recommended limits. To determine minimum fungicidal concentration (MFC) [3] values, after reading the corresponding MIC values, $10 \mu \mathrm{l}$ samples from all optically clear tubes (complete growth inhibition) plus the

\footnotetext{
EMBRAPA Arroz e Feijão, 75375-000, Santo Antônio de Goiás-GO, Brazil
} Full list of author information is available at the end of the article last tube showing growth were subcultured on Sabouraud Dextrose Aagar Petri dishes. The dishes were incubated at $35^{\circ} \mathrm{C}$ for for 3 days, until growth was clearly visible in the control samples, and MFC values were determined as the lowest concentration EO which there was no visible growth.

\section{Results and conclusions}

A. balsamifera EO exhibited wide-spectrum antifungal activity. Evaluation of MIC and MFC values showed that the EO was active against all the tested strains. MIC values ranged from 128 to $256 \mu \mathrm{g} / \mathrm{mL}$ against Cryptococcus, and MFC values were between 128 to $512 \mu \mathrm{g} / \mathrm{mL}$. Acording to Scorzoni [4] compounds with MICs $\leq 256 \mu \mathrm{g} / \mathrm{mL}$ are considered relevant in the investigation of substances for therapeutic purposes, so in our study we can conclude that the EO showed antifungal activity against yeasts of the complex C. neoformans.

\section{Acknowledgements}

UFG, Embrapa Arroz e Feijão e Embrapa Cenargen

\section{Authors' details}

${ }^{1}$ Instituto de Patologia Tropical e Saúde Pública (IPTSP), Universidade Federal de Goiás, 74605-050, Goiânia-GO, Brazil. EMBRAPA Arroz e Feijão, 75375-000, Santo Antônio de Goiás-GO, Brazil. ${ }^{3}$ EMBRAPA Recursos Genéticos e Biotecnologia - Parque Estação Biológica, 70770-910, Brasília-DF, Brazil.

Published: 1 October 2014

\section{References}

1. Li SS, Mody CH: Cryptococcus. Ann Am Thorac Soc 2010, 7:186-196.

2. CLSI: Reference Method for Broth Dilution Antifungal Susceptibility Testing of Yeasts. Approved Standard M27- A3. Wayne, PA: Clinical and Laboratory Standards Institute; 32008.

3. De Logu A, Saddi M, Cardia MC, Borgna R, Sanna C, Saddi B, Maccioni E: In vitro activity of 2-cycohexylidenhydrazo-4-phenyl-thiazole compared with those of amphotericin B and fluconazole against clinical isolates of Candida spp. and fluconazole resistant Candida albicans. J Antimicrob Chemother 2005, 55:692-698. 
4. Scorzoni L, Benaducci T, Almeida AMF, Silva DHS, Bolzani VS, Mendes-Giannini MJS: Comparative study of disk diffusion and microdilution methods for evaluation of antifungal activity of natural compounds against medical yeasts Candida spp and Cryptococcus sp. Rev Ciênc Farm Básica Apl 2007, 18:25-34.

doi:10.1186/1753-6561-8-S4-P32

Cite this article as: Abrão et al: Antifungal activity of essential oil of Amyrisbalsamifera against Cryptococcusneoformans. BMC Proceedings 2014 8(Suppl 4):P32.

Submit your next manuscript to BioMed Central and take full advantage of:

- Convenient online submission

- Thorough peer review

- No space constraints or color figure charges

- Immediate publication on acceptance

- Inclusion in PubMed, CAS, Scopus and Google Scholar

- Research which is freely available for redistribution

Submit your manuscript at www.biomedcentral.com/submit 